\title{
Inhibition of $\gamma$-Secretase Cleavage in the Notch Signaling Pathway Blocks HSV-2-Induced Type I and Type II Interferon Production
}

\author{
Alexandra Svensson, Emely Jäkärä, Andrey Shestakov, and Kristina Eriksson
}

\begin{abstract}
We have evaluated the role of $\gamma$-secretase, which is a crucial component in the Notch-induced signaling cascade, on herpes simplex virus type 2 (HSV-2)-induced innate and acquired interferon responses in human CD4 ${ }^{+} \mathrm{T}$ cells and plasmacytoid dendritic cells (pDC). We found that blockade of the Notch signaling pathway with a pharmacological $\gamma$-secretase inhibitor blocked both HSV-2-induced interferon- $\gamma$ (IFN- $\gamma$ ) production in CD4 ${ }^{+} \mathrm{T}$ cells, and HSV-2-induced IFN- $\alpha$ production in $\mathrm{pDC}$ in a dose-dependent fashion. These effects were not due to an overall suppressive capacity of the $\gamma$-secretase inhibitor, as it affected neither phytohemagglutinin (PHA)induced IFN- $\gamma$ production in $\mathrm{CD}^{+}{ }^{+} \mathrm{T}$ cells, nor $\mathrm{CpG}$-induced IFN- $\alpha$ production in $\mathrm{pDC}$. Our data suggest that Notch signaling could be involved in HSV-2-induced interferon responses in $\mathrm{CD}^{+}{ }^{+} \mathrm{T}$-cells and pDC.
\end{abstract}

\section{Introduction}

G ENITAL INFECTION CAUSED By HERPES SIMPLEX VIRUS TYPE 2 (HSV-2) is the most common sexually transmitted ulcerative disease worldwide. About one-fourth of the adult Swedish population is affected by genital HSV-2 infection $(2,6,21)$. The clinical effects of HSV-2 infection range from no symptoms (asymptomatic infection) to severe and recurrent episodes of genital and non-genital symptoms. The host defense mechanisms against HSV-2 infection involve both natural and acquired immune responses, in which interferons play an essential role in immunity against the infection. Studies in mice show that interferon (IFN)- $\alpha / \beta$-receptor signaling is crucial for an efficient innate immune response to HSV-2 $(18,29)$. Mice deficient in the IFN- $\alpha / \beta$ receptor have significantly higher viral titers and a totally abolished IFN- $\alpha$ production (29). However, IFN- $\alpha / \beta$-receptor signaling does not appear to be involved in the development of the acquired immunity to HSV-2 (29). IFN- $\gamma$, on the other hand, is required both for innate and acquired immunity to HSV-2. In vaccinated mice, IFN- $\gamma$ together with $\mathrm{CD}^{+}{ }^{+} \mathrm{T}$ cells comprise the most important components in acquired protective immunity to the infection $(9,28)$. In humans, impaired HSV-2-specific IFN- $\gamma$ responses correlate with recurrent clinical disease, whereas high levels of IFN- $\gamma$ are produced in T cells from individuals with asymptomatic HSV-2 infection $(5,28)$. Furthermore, mice lacking either IFN- $\gamma$ or $\mathrm{CD} 4^{+} \mathrm{T}$-cells cannot mount a protective immune response to HSV-2 after vacci- nation $(9,10)$. However, treating mice with IFN- $\gamma$ can bypass the requirement for $\mathrm{CD}^{+} \mathrm{T}$ cells, indicating that the main function of $\mathrm{CD}^{+}{ }^{+}$T cells in HSV-2 infection is to produce $\operatorname{IFN}-\gamma(9)$.

Plasmacytoid dendritic cells (pDC) are the main type I IFN producers in the body (14), and they produce high levels of IFN- $\alpha$ in response to HSV-2 by the binding of genomic DNA from HSV-2 to TLR9 $(13,14)$. Fibroblasts and macrophages also express type 1 IFN, and in these cells the recognition of viral infection is mediated by the retinoic acid-inducible gene-I (RIG)-I together with TLR9, a process that is also dependent on RNaseL $(24,25)$. Other factors known to induce IFN production after HSV binding include the mannose receptor $(15,26)$, and the chemokine receptors CCR3 and CXCR4 (1). Type II IFN, on the other hand, is mainly secreted by natural killer cells and T cells $(3,27)$.

Notch proteins (Notch1-4) are transcriptional activators expressed in a wide range of immune cells (23). Following interaction with either of its ligands, the Notch/ligand complex is cleaved first by a metalloprotease, and then by $\gamma$-secretase. These processes generate an active intracellular portion of Notch (NotchIC), that can translocate to the nucleus and act as a transcription activator $(7,8,17)$. Notch proteins are involved in the development of a wide range of fetal and postnatal processes, and their role in hematopoiesis and thymocyte development are well documented (23). More recent studies also address a role for the Notch proteins in the regulation of peripheral T-cell responses, including $\mathrm{CD} 4^{+}$

Department of Rheumatology and Inflammation Research, University of Gothenburg, Gothenburg, Sweden. 
T-cell activation and IFN- $\gamma$ induction (20). In this study we wanted to investigate whether Notch signaling is involved in HSV-2-specific IFN responses in $\mathrm{CD}^{+}{ }^{+} \mathrm{T}$ cells and in $\mathrm{pDC}$.

It has previously been shown that Notch signaling can be blocked with a $\gamma$-secretase inhibitor, and that this will decrease the IFN- $\gamma$ production in CD3/CD28-stimulated CD4 $4^{+}$ $\mathrm{T}$ cells under neutral or Th-1-driving conditions (16). We verified these results and showed that the $\mathrm{CD} 4^{+} \mathrm{T}$-cell response to HSV-2 can be blocked by inhibiting $\gamma$-secretase cleavage in the Notch-signaling pathway.

First, we confirmed the expression of Notch1 on PBMC. As expected, the Notch1 receptor was expressed on the surface of $\mathrm{CD}^{+} \mathrm{T}$ cells (Fig. 1A). To assess the role of $\gamma$-secretase signaling in HSV-2-mediated IFN- $\gamma$ responses, purified $\mathrm{CD}^{+}{ }^{+} \mathrm{T}$ cells were stimulated with irradiated HSV-2 in the presence or absence of the $\gamma$-secretase inhibitor compound E (CalBiochem, San Diego, CA) at different concentrations. The $\gamma$-secretase inhibitor completely blocked the production of IFN- $\gamma$ from $\mathrm{CD} 4^{+} \mathrm{T}$ cells, while the non-treated cells produced IFN- $\gamma$, albeit at different levels, in response to HSV-2 (Fig. 1B). This inhibition was dose-dependent, since $\mathrm{CD} 4^{+} \mathrm{T}$ cells stimulated with the $\gamma$-secretase inhibitor were totally incapable of producing any IFN- $\gamma$ at inhibitor concentrations higher than $5.6 \mu \mathrm{M}$ (range $50-5.6 \mu \mathrm{M}$; Fig. 1C). At lower concentrations $(1.8 \mu \mathrm{M})$, the amount of IFN- $\gamma$ produced was comparable to that seen in cultures without any inhibitor added (Fig. 1C). The inhibition of IFN- $\gamma$ production in HSV-2-activated $\mathrm{CD}^{+} \mathrm{T}$ cells was not due to an overall suppressive ability of the $\gamma$-secretase inhibitor, as seen after CD3/CD28 stimulation (16), since PHA-induced IFN- $\gamma$ production in $\mathrm{CD}^{+} \mathrm{T}$ cells remained unaffected after culture with the inhibitor (Fig. 1D). This indicates that HSV-2mediated IFN- $\gamma$ production is dependent on the Notchsignaling pathway, suggesting a new, previously unknown intracellular signaling pathway downstream of the Notch cascade in the $\mathrm{CD} 4^{+}$T-cell response against HSV-2 infection. Blockade of $\gamma$-secretase cleavage under Th-1-polarizing conditions inhibits the activation of the transcription factor T-
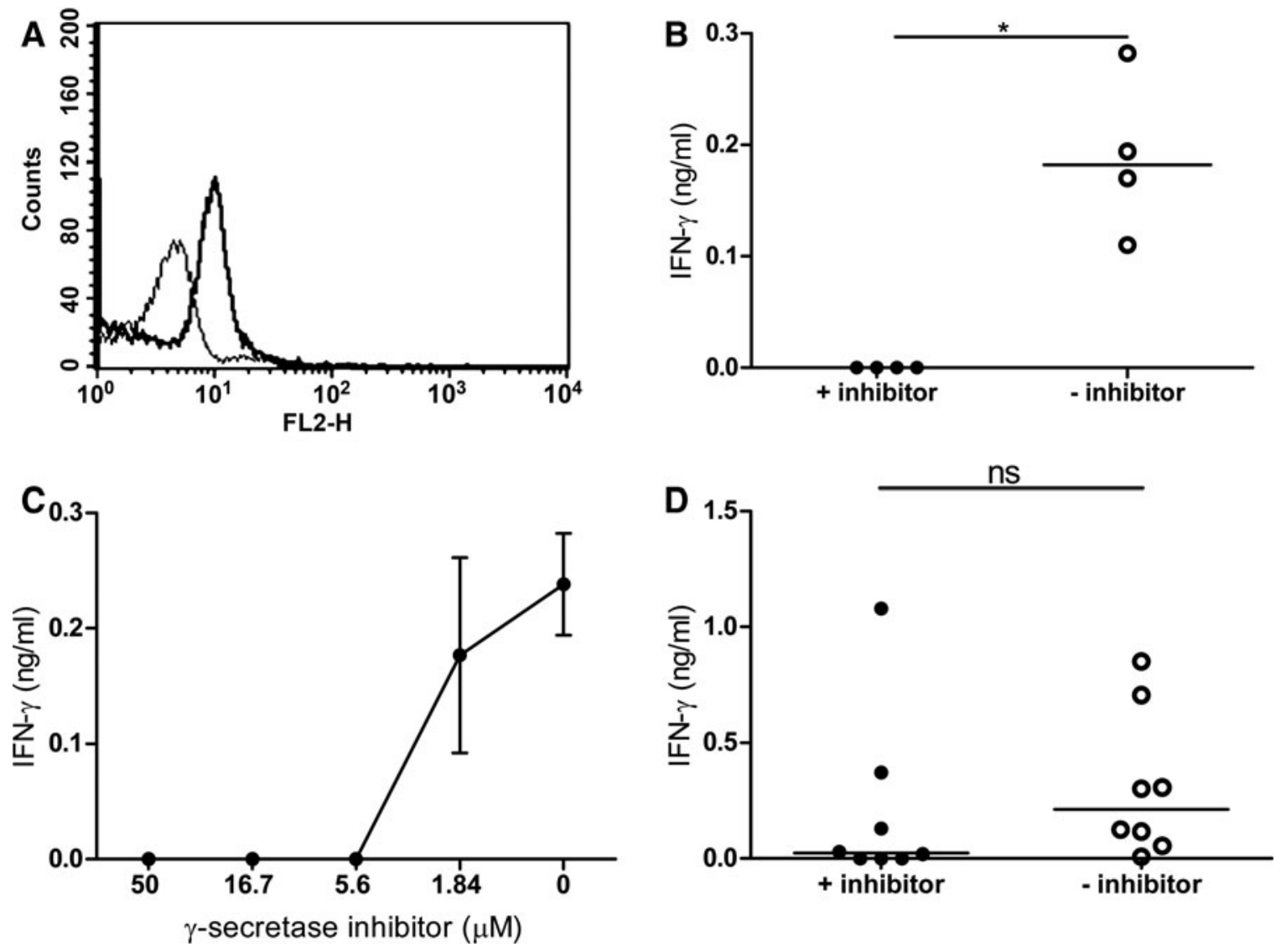

FIG. 1. Inhibition of $\gamma$-secretase cleavage blocks HSV-2-induced IFN- $\gamma$ production in CD4 ${ }^{+} \mathrm{T}$ cells. (A) To confirm the expression of Notch1 on CD4 ${ }^{+} \mathrm{T}$ cells, PBMC were stained with $\alpha$-CD4-PerCp and $\alpha$-Notch1-PE (thick black line) or the isotype control $\alpha$-mouse- $\gamma 1$ (thin black line). IFN- $\gamma$ production was measured with a duo set ELISA kit (R\&D Systems, Inc., Minneapolis, MN) in pooled supernatants from duplicates of $\mathrm{CD}^{+}{ }^{\mathrm{T}}$ cells (purified from PBMC with a Dynal CD4 ${ }^{+}$Isolation Kit; Invitrogen, Carlsbad, CA) after $48 \mathrm{~h}$ of culture in Iscoves' complete medium, at a concentration of $10^{5}$ cells/well in flatbottomed 96-microwell plates, in a total volume of $200 \mu \mathrm{L}$. The cells were stimulated with $4 \times 10^{5} \mathrm{pfu} / \mathrm{mL}$ of UV-inactivated HSV-2 333 virions (B), or $2.5 \mu \mathrm{g} / \mathrm{mL}$ of phytohemagglutinin (D). Stimulated cells were also cultured with $50 \mu \mathrm{M}$ (solid circles in $\mathbf{B}$ and $\mathbf{D})$, or different concentrations (C), of the $\gamma$-secretase inhibitor compound $\mathbf{E}$ (CalBiochem), or medium alone (open circles in B and D) containing 0.01\% DMSO (corresponding to the DMSO concentration in $100 \mu \mathrm{M} \gamma$-secretase inhibitor). Data represent the individuals (circles), and the median (line) IFN- $\gamma$ production from four different donors (B), or eight different donors (D), and the mean IFN- $\gamma$ production/group \pm SEM $\left(\mathbf{C} ; \mathrm{n}=2 ;{ }^{*} p<0.05\right.$ by the Mann-Whitney $U$ test). 
bet, which leads to diminished IFN- $\gamma$ production (16). It is possible that the abolished IFN- $\gamma$ production seen after $\gamma$ secretase blockade of HSV-2-activated $\mathrm{CD}^{+}{ }^{+} \mathrm{T}$ cells is due to the inhibition of T-bet in a similar manner, since T-bet is essential to HSV-2-induced immunity (30). However, this remains to be evaluated.

Dontje et al. have previously shown that Notch1 is expressed on $\mathrm{CD}_{3} 4^{+}$precursor cells, and that the level of Notch1 expression decreases when the precursor cells differentiate into pDC (4). Interaction of Notch1 on CD $34^{+}$ progenitor cells with its ligand delta- 1 leads to the maturation of $\mathrm{pDC}$, a development that can be blocked with a $\gamma$-secretase inhibitor (19). Here, we show that mature pDC also express the Notch1 receptor (Fig. 2A), and that their IFN- $\alpha$ production is almost completely abolished after blockade of the $\gamma$-secretase cleavage step in response to HSV2 (Fig. 2B). It has previously been shown that HSV-2 can induce IFN- $\alpha$ production in murine $\mathrm{pDC}$, by the binding of genomic viral DNA to TLR9, and signaling through MyD88
(13). We confirm that $\mathrm{pDC}$ produce IFN- $\alpha$ in response to irradiated HSV-2 (Fig. 2B), via TLR9 ligation (Fig. 3A). TLR9 signaling is induced by the binding of $\mathrm{CpG}$-rich motifs to the receptor, which gives rise to high levels of IFN- $\alpha$. The stimulatory effect of $\mathrm{CpG}$ can be blocked with a G-ODN that is characterized by the presence of a repetitive sequence of five guanosines and no stimulatory CpG motifs (22). Indeed, the stimulatory effect of $\mathrm{CpG}$ in our system was blocked after stimulation with $\mathrm{CpG}$ and G-ODN (Fig. 3B). More importantly, we also show that HSV-2 strain 333 signals through TLR9, since pDC stimulated with the virus together with GODN produced reduced amounts of IFN- $\alpha$ (Fig. 3A). However, the IFN- $\alpha$ production from HSV-2-stimulated pDC was almost completely abolished by the $\gamma$-secretase inhibitor (Fig. 2B). Similarly to the inhibition of IFN- $\gamma$ secretion in $\mathrm{CD}^{+} \mathrm{T}$ cells, the inhibition of IFN- $\alpha$ production also occurred in a dose-dependent fashion (Fig. 2C). pDC cultured with high doses of the $\gamma$-secretase inhibitor $(100 \mu \mathrm{M})$ produced very low amounts of IFN- $\alpha$, which increased with decreasing
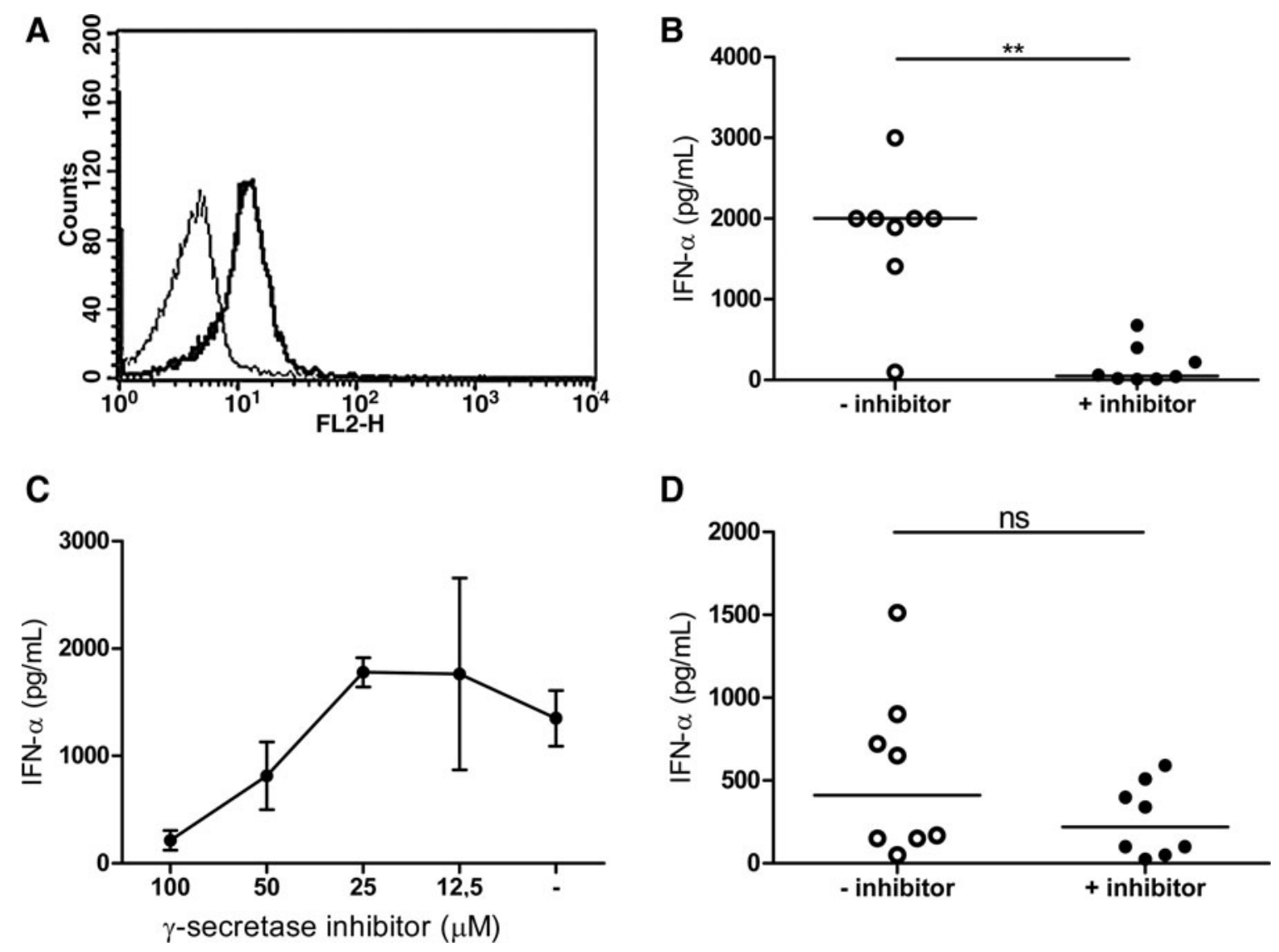

FIG. 2. Inhibition of $\gamma$-secretase cleavage blocks HSV-2-induced IFN- $\alpha$ production in pDC. (A) To confirm the expression of Notch1 on pDC, purified pDC were stained with $\alpha$-Notch1-PE (thick black line), or the isotype control $\alpha$-mouse- $\gamma 1$ (thin black line). IFN- $\alpha$ production was measured with an hIFN- $\alpha$ ELISA Kit (PBL Biomedical Laboratories, Piscataway, NJ) in pooled supernatants from duplicates of purified pDC (positive cells were selected from PBMC with the Magnetic Cell Sorting of Human Cells [MACS] BDCA-4 Cell Isolation Kit; Miltenyi Biotech, Auburn, CA), after 24h of culture in Iscoves' complete medium, at a concentration of $10^{5}$ cells/well (in flat-bottomed 96-microwell plates) in a total volume of $200 \mu \mathrm{L}$. The cells were stimulated with $4 \times 10^{5} \mathrm{pfu} / \mathrm{mL}$ of UV-inactivated HSV-2 333 virions (B), or $10 \mu \mathrm{g} / \mathrm{mL}$ of CpG (D). Stimulated cells were also cultured with $100 \mu \mathrm{M}$ (solid circles in B and D), or different concentrations (C), of the $\gamma$-secretase inhibitor compound E, or medium alone (open circles in B and D) containing 0.01\% DMSO (corresponding to the DMSO concentration in $100 \mu \mathrm{M}$ $\gamma$-secretase inhibitor). Data represent the individual and the median production of IFN- $\alpha$ from eight different donors (B and D), and the mean IFN- $\alpha$ production/group from $\pm \operatorname{SEM}\left(\mathbf{C} ; \mathrm{n}=5 ;{ }^{* *} p<0.01\right.$ by the Mann-Whitney $U$ test). 

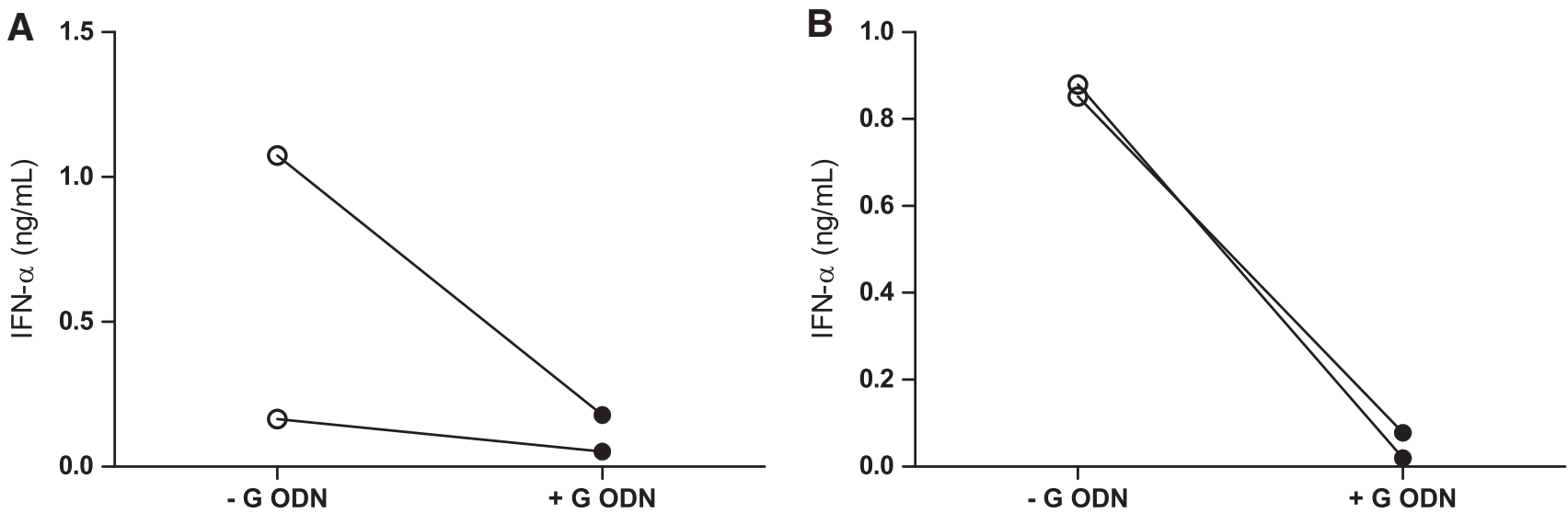

FIG. 3. Blockade of TLR9 inhibits HSV-2- (A) and CpG-induced (B) IFN- $\alpha$ production in pDC. IFN- $\alpha$ production was measured with an hIFN- $\alpha$ ELISA Kit, in supernatants from purified pDC (positive cells were selected from PBMC with the Magnetic Cell Sorting of Human Cells [MACS] BDCA-4 Cell Isolation Kit) after $24 \mathrm{~h}$ of culture in Iscoves' complete medium, at a concentration of $10^{5}$ cells/well (in flat-bottomed 96-microwell plates), in a total volume of $200 \mu \mathrm{L}$. The cells were stimulated with $4 \times 10^{5} \mathrm{pfu} / \mathrm{mL}$ of UV-inactivated HSV-2 333 virions (open circles in A), or $10 \mu \mathrm{g} / \mathrm{mL}$ of CpG (open circles in B). Stimulated cells were also cultured with $15 \mu \mathrm{M}$ of a TLR9-blocking ODN (G-ODN; Invitrogen; filled circles in A and B). Data represent the individual IFN- $\alpha$ production in the supernatant from two different donors.

concentrations $(100-25 \mu \mathrm{M})$ of the inhibitor (Fig. 2C). The inhibition of IFN- $\alpha$ production was particularly impressive in HSV-2-exposed pDC (Fig. 2B), whereas the CpG-induced IFN- $\alpha$ production was less affected, perhaps due to the lower IFN- $\alpha$ responses obtained with CpG (Fig. 2D). This indicates that the Notch $/ \gamma$-secretase pathway might be involved in the HSV-2-induced IFN- $\alpha$ production. Thus, both the Notch/ $\gamma$-secretase pathway and the TLR9/IRF-7/MyD88 pathways $(11,12)$ might be required for adequate HSV-2induced IFN $-\alpha$ responses in $\mathrm{pDC}$. This supports the notion that the type I IFN pathways are complex, and involve several pathways that interact both prior to, and during, the IFN response.

In conclusion, we show that blocking Notch signaling through the administration of a $\gamma$-secretase inhibitor completely blocks IFN- $\gamma$, and clearly diminishes IFN- $\alpha$ production in $\mathrm{CD}^{+} \mathrm{T}$ cells and $\mathrm{pDC}$, respectively. Both type I and type II IFNs are essential to combat HSV-2 infection $(5,18,28,29)$, and blockade of the $\gamma$-secretase signaling pathway may increase both the risk and the severity of genital HSV-2 infection. This is important to take into consideration in the medical therapy of, for example, Alzheimer's patients, in whom $\gamma$-secretase inhibitors are commonly used as treatment. Thus we suggest that Notch signaling, via the cleavage of $\gamma$-secretase, could be involved in HSV-2-induced interferon responses in both $\mathrm{CD}^{+}{ }^{+} \mathrm{T}$ cells and in $\mathrm{pDC}$, via yet unknown downstream pathways.

\section{Author Disclosure Statement}

No competing financial interests exist.

\section{References}

1. Ankel H, Westra DF, Welling-Wester S, and Lebon P: Induction of interferon-alpha by glycoprotein $\mathrm{D}$ of herpes simplex virus: a possible role of chemokine receptors. Virology 1998;251:317-326.
2. Berntsson M, Tunback P, Ellstrom A, Krantz I, and Lowhagen GB: Decreasing prevalence of herpes simplex virus-2 antibodies in selected groups of women in Sweden. Acta Derm Venereol 2009;89:623-626.

3. Biron CA, Nguyen KB, Pien GC, Cousens LP, and SalazarMather TP: Natural killer cells in antiviral defense: function and regulation by innate cytokines. Annu Rev Immunol 1999;17:189-220.

4. Dontje W, Schotte R, Cupedo T, et al.: Delta-like1-induced Notch1 signaling regulates the human plasmacytoid dendritic cell versus T-cell lineage decision through control of GATA-3 and Spi-B. Blood 2006;107:2446-2452.

5. Eriksson K, Bellner L, Gorander S, Lowhagen GB, Tunback $\mathrm{P}$, Rydberg K, and Liljeqvist JA: CD4(+) T-cell responses to herpes simplex virus type 2 (HSV-2) glycoprotein $\mathrm{G}$ are type specific and differ in symptomatic and asymptomatic HSV2-infected individuals. J Gen Virol 2004;85:2139-2147.

6. Forsgren M, Skoog E, Jeansson S, Olofsson S, and Giesecke J: Prevalence of antibodies to herpes simplex virus in pregnant women in Stockholm in 1969, 1983 and 1989: implications for STD epidemiology. Int J STD AIDS 1994;5:113-116.

7. Fortini ME: Gamma-secretase-mediated proteolysis in cellsurface-receptor signalling. Nat Rev Mol Cell Biol 2002;3: 673-684.

8. Fryer CJ, Lamar E, Turbachova I, Kintner C, and Jones KA: Mastermind mediates chromatin-specific transcription and turnover of the Notch enhancer complex. Genes Dev 2002; 16:1397-1411.

9. Harandi AM, Svennerholm B, Holmgren J, and Eriksson K: Differential roles of $\mathrm{B}$ cells and IFN-gamma-secreting $\mathrm{CD} 4(+) \mathrm{T}$ cells in innate and adaptive immune control of genital herpes simplex virus type 2 infection in mice. J Gen Virol 2001;82:845-853.

10. Harandi AM, Svennerholm B, Holmgren J, and Eriksson K: Interleukin-12 (IL-12) and IL-18 are important in innate defense against genital herpes simplex virus type 2 infection in mice but are not required for the development of acquired gamma interferon-mediated protective immunity. J Virol 2001;75:6705-6709. 
11. Honda K, Yanai H, Takaoka A, and Taniguchi T: Regulation of the type I IFN induction: a current view. Int Immunol 2005;17:1367-1378.

12. Kawai T, and Akira S: Pathogen recognition with Toll-like receptors. Curr Opin Immunol 2005;17:338-344.

13. Lund J, Sato A, Akira S, Medzhitov R, and Iwasaki A: Tolllike receptor 9-mediated recognition of Herpes simplex virus- 2 by plasmacytoid dendritic cells. J Exp Med 2003;198: 513-520.

14. Malmgaard L: Induction and regulation of IFNs during viral infections. J Interferon Cytokine Res 2004;24:439-454.

15. Milone MC, and Fitzgerald-Bocarsly P: The mannose receptor mediates induction of IFN-alpha in peripheral blood dendritic cells by enveloped RNA and DNA viruses. J Immunol 1998;161:2391-2399.

16. Minter LM, Turley DM, Das P, et al.: Inhibitors of gammasecretase block in vivo and in vitro $\mathrm{T}$ helper type 1 polarization by preventing Notch upregulation of Tbx21. Nat Immunol 2005;6:680-688.

17. Mumm JS, and Kopan R:, Notch signaling: from the outside in. Dev Biol 2000;228:151-165.

18. Murphy JA, Duerst RJ, Smith TJ, and Morrison LA: Herpes simplex virus type 2 virion host shutoff protein regulates alpha/beta interferon but not adaptive immune responses during primary infection in vivo. J Virol 2003;77:9337-9345.

19. Olivier A, Lauret E, Gonin P, and Galy A: The Notch ligand delta-1 is a hematopoietic development cofactor for plasmacytoid dendritic cells. Blood 2006;107:2694-2701.

20. Palaga T, Miele L, Golde TE, and Osborne BA: TCRmediated Notch signaling regulates proliferation and IFNgamma production in peripheral T cells. J Immunol 2003; 171:3019-3024.

21. Persson K, Mansson A, Jonsson E, and Nordenfelt E: Decline of herpes simplex virus type 2 and Chlamydia trachomatis infections from 1970 to 1993 indicated by a similar change in antibody pattern. Scand J Infect Dis 1995;27:195-199.

22. Peter M, Bode K, Lipford GB, Eberle F, Heeg K, and Dalpke $\mathrm{AH}$ : Characterization of suppressive oligodeoxynucleotides that inhibit Toll-like receptor-9-mediated activation of innate immunity. Immunology 2008;123:118-128.

23. Radtke F, Wilson A, Mancini SJ, and MacDonald HR: Notch regulation of lymphocyte development and function. Nat Immunol 2004;5:247-253.
24. Rasmussen SB, Jensen SB, Nielsen C, et al.: Herpes simplex virus infection is sensed by both Toll-like receptors and retinoic acid-inducible gene-like receptors, which synergize to induce type I interferon production. J Gen Virol 2009;90:7478.

25. Rasmussen SB, Sorensen LN, Malmgaard L, Ank N, Baines JD, Chen ZJ, and Paludan SR: Type I interferon production during herpes simplex virus infection is controlled by cell-type-specific viral recognition through Toll-like receptor 9, the mitochondrial antiviral signaling protein pathway, and novel recognition systems. J Virol 2007;81:1331513324.

26. Rong Q, Alexander TS, Koski GK, and Rosenthal KS: Multiple mechanisms for HSV-1 induction of interferon alpha production by peripheral blood mononuclear cells. Arch Virol 2003;148:329-344.

27. Sen GC: Viruses and interferons. Annu Rev Microbiol 2001; 55:255-281.

28. Singh R, Kumar A, Creery WD, Ruben M, Giulivi A, and Diaz-Mitoma F: Dysregulated expression of IFN-gamma and IL-10 and impaired IFN-gamma-mediated responses at different disease stages in patients with genital herpes simplex virus-2 infection. Clin Exp Immunol 2003;133:97107.

29. Svensson A, Bellner L, Magnusson M, and Eriksson K: Role of IFN-alpha/beta signaling in the prevention of genital herpes virus type 2 infection. J Reprod Immunol 2007;74: 114-123.

30. Svensson A, Nordstrom I, Sun JB, and Eriksson K: Protective immunity to genital herpes simplex [correction of simpex] virus type 2 infection is mediated by T-bet. J Immunol 2005; 174:6266-6273.

Address correspondence to: Dr. Alexandra Svensson

Department of Rheumatology and Inflammation Research University of Gothenburg Guldhedsgatan $10 \mathrm{~A}$ 41346 Gothenburg, Sweden

E-mail: alexandra.svensson@microbio.gu.se

Received January 22, 2010; accepted March 15, 2010. 
